\title{
PENGARUH PENDEKATAN PEMBELAJARAN HUMANISTIK TERHADAP HASIL BELAJAR SISWA PADA MATA PELAJARAN IPS KELAS VII DI SMP NEGERI 8 KOTA CIREBON
}

\author{
Nurhakiki $^{1}$, Ratna Puspitasari ${ }^{2}$ \\ IAIN Syekh Nurjati Cirebon ${ }^{1,2}$ \\ nurhakiki823@yahoo.co.id;puspitasariratna72@yahoo.com
}

\begin{abstract}
Abstrak
Latar belakang permasalahan penelitian ini terkait etika peserta didik di sekolah tersebut dikatakan cukup memprihatinkan, disekolah tersebut telah menerapkan KURTILAS, dalam proes pembelajaran guru dituntut untuk dapat mengikuti kurikulum yang ada dengan pendekatan Scientific, guru berupaya semampunya dalam proses pembelajaran menggunakan metode bervariasi, didukung media disekolah cukup memadai, tetapi pada kenyataannya masih banyak peserta didik mengalami kesulitan, bahkan hasil belajarnyapun masih banyak siswa tidak mencapai KKM.Tujuan penelitian ini untuk mengetahui penerapan pendekatan pembelajaran humanistik pada pelajaran IPS kelas 7, untuk mengetahui hasil belajar siswa pada pelajaran IPS di kelas 7 setelah menggunakan pendekatan humanistik, untuk mengetahui pengaruh penerapan pendekatan pembelajaran humanistik terhadap hasil belajar siswa kelas 7 di SMPN 8 Kota Cirebon.Pembelajaran dalam pendekatan humanistik dipahami sebagai pembelajaran yang mengarah pada proses memanusiakan manusia. Penelitian ini didasarkan pada sebuah asumsi bahwa pembelajaran harus memperhatikan siswa sebagai manusia yang memiliki karakter dan perbedaan individual. Siswa diarahkan agar dapat mengembangkan potensi dirinya tanpa ada tekanan, paksaan, ataupun kekerasan dari guru.Jenis penelitian ini kuantitatif Eksperimen. Teknik dan instrumen pengumpulan datanya observasi ,wawancara, Tes (Pre-Post Test), Angket dan dokumentasi. Teknik analisi datanya uji skala prosentase, uji normalitas, uji homogenitas, analisis butir soal, uji analisis korelasi, koefisien determinasi, analisis regresi linear, uji “t”. Populasi penelitian ini seluruh siswa kelas 7 dengan sampel 2 kelas (kelas $7 \mathrm{G}$ dan $7 \mathrm{H}$ ). Hasil penelitian ini berdasarkan analisi data angket pembelajaran humanistik mendapatkan respon yang "cukup" dari siswa dengan interval presentase (41-60\%). Hal ini ditunjukkan dengan sebagian besar siswa (41,55\%)menjawab "setuju”. Hasil belajarnya diperoleh rata-rata nilai Post-Test 81,33, yang artinya hasil belajar siswa "baik" dengan interval persentase (76-85\%). Hasil perhitungan spss v.22 menunjukkan bahwa nilai signifikansi 0,000 $<0,05$ dengan demikian $\mathrm{H}_{0}$ ditolak dan $\mathrm{H}_{\mathrm{a}}$ diterima, artinya terdapat pengaruh signifikan pada penerapan pendekatan pembelajaran humanistik terhadap hasil belajar siswa pada mata pelajaran IPS kelas 7 di SMPN 8 Kota Cirebon.
\end{abstract}

Kata Kunci: Pembelajaran, Humanistik, Hasil Belajar. 


\begin{abstract}
The background of this research problem related to the ethics of students in the school is said to be quite apprehensive, the school has applied KURTILAS, in the proes of learning teachers are required to be able to follow the existing curriculum with Scientific approach, the teacher strives to the best in the learning process using varied methods, supported by enough media media adequate, but in reality there are still many students having difficulties, even the result of learning is still many students do not reach KKM. The purpose of this research is to know the application of humanistic learning approach in 7th grade IPS lesson, to know the result of student learning in IPS lesson in 7th grade after using humanistic approach to know the influence of humanistic learning approach to the 7th grade student learning at SMPN 8 Kota Cirebon. Learning in a humanistic approach is understood as a learning that leads to the process of humanizing humans. This study is based on an assumption that learning should pay attention to students as human beings who have individual character and differences. Students are directed to develop their potential without any pressure, coercion, or violence from the teacher. This type of research is quantitative experiments. Techniques and instruments of data collection of observation, interview, test (Pre-Post Test), Questionnaire and documentation. Technique of data analysis of test of percentage scale, normality test, homogeneity test, item item analysis, correlation analysis test, coefficient of determination, linear regression analysis, $t$ test. The population of this study were all seventh grade students with a sample of 2 classes (grade $7 \mathrm{G}$ and $7 \mathrm{H}$ ). The results of this study were based on humanistic learning questionnaire data analysis getting "enough" response from students with percentage interval (41-60\%). This is indicated by the majority of students (41.55\%) responding "agree". The learning results obtained an average Post-Test value of 81.33, which means the learning outcomes of students "good" with a percentage interval (76-85\%). The result of spss v.22 shows that the significance value 0.000 $<0,05$ thus $H_{0}$ is rejected and $H_{a}$ accepted, meaning there is significant influence on applying humanistic learning approach to student learning outcomes in 7th grade IPS in SMPN 8 Cirebon.
\end{abstract}

Keywords: Learning, Humanistic, Learning Outcomes.

\title{
A. PENDAHULUAN
}

\section{Latar Belakang Masalah}

Pendidikan merupakan suatu kegiatan yang universal dalam kehidupan menusia, yang diwujudkan dalam usaha pembelajaran, keterampilan dan kebiasaan seorang yang diturunkan dari satu generasi ke generasi berikutnya melalui pengajaran, penelitian dan pelatihan. Dimanapun terdapat masyarakat, maka disitulah terdapat pendidikan. 
Pendidikan yang dilaksanakan di Indonesia dapat di lihat dari tujuan Pendidikan Nasional yang tercantum dalam UU No. 20 Tahun 2003 tentang Sistem Pendidikan Nasional yang menyebutkan bahwa :

"Pendidikan Nasional berfungsi mengembangkan kemampuan dan membentuk watak serta peradaban bangsa yang bermartabat dalam rangka mencerdaskan kehidupan bangsa, bertujuan untuk berkembangnya potensi peserta didik agar menjadi manusia yang beriman dan bertakwa kepada Tuhan Yang Maha Esa, berakhlak mulia, sehat, berilmu, cakap, kreatif, mandiri, dan menjadi warga negara yang demokratis serta bertanggung jawab.” ( Sisdiknas, 2003). Pendekatan pembelajaran humanistik memandang bahwa pada

hakekatnya setiap diri manusia adalah unik, memiliki potensi individual dan dorongan internal untuk berkembang dan menentukan perilakunya, manusia dianggap sebagai subyek yang bebas merdeka untuk menentukan arah hidupnya, serta bertanggung jawab penuh atas hidupnya sendiri dan juga atas hidup orang lain.

Berdasarkan survei peneliti sebelumnya, peneliti menemukan beberapa permasalahan yang terdapat di sekolah tersebut yakni terkait dengan tingkat etika peserta didik di sekolah tersebut yang bisa dikatakan cukup memprihatinkan,misalnya saja banyak siswa yang kurang sopan dalam berbicara dan berperilaku terhadap temannya, kurangnya penanaman etika pada diri peserta didik ini menyebabkan merosotnya moral generasi muda yang tidak sesuai aturan yang telah ditetapkan, meskipun disekolah tersebut berusaha mewujudkan aturan sekolah seperti di MTs namun hal tersebut masih belum menjadikan perilaku peserta didik menjadi baik. Di sekolah tersebut telah menerapkan KURTILAS meski belum secara universal terkecuali untuk kelas 9 yang masih menggunakan KTSP, namun dalam proes pembelajaran guru-guru disekolah tersebut sudah dituntut untuk dapat mengikuti kurikulum yang ada dengan pendekatan Scientific, guru-guru berupaya semampunya dalam proses pembelajaran dengan menggunakan metode yang bervariasi dengan didukung media yang ada disekolah ckup memadai, tetapi pada kenyataannya masih banyak peserta 
didik yang mengalami kesulitan dalam pembelajaran, bahkan dalam hasil belajarnyapun masih banyak siswa yang tidak mencapai KKM yang telah ditetapkan sekolah.

Berdasarkan permasalahan diatas peneliti bermaksud melaksanakan Penelitian dengan judul "Pengaruh Pendekatan Pembelajaran Humanistik Terhadap Hasil Belajar Siswa Pada Mata Pelajaran IPS Kelas VII Di SMP Negeri 8 Kota Cirebon”.

\section{Rumusan Masalah}

Melihat permasalahan yang diuraikan dalam latar belakang, maka peneliti menyimpulkan suatu rumusan masalah sebagi berikut :

a. Bagaimana penerapan pendekatan pembelajaran humanistik pada mata pelajaran IPS kelas VII di SMP Negeri 8 Kota Cirebon?

b. Bagaimana hasil belajar siswa pada mata pelajaran IPS di kelas VII setelah menggunakan pendekatan pembelajaran humanistik di SMP Negeri 8 Kota Cirebon?

c. Seberapa besar pengaruh penerapanpendekatan pembelajaran humanistik terhadap hasil belajar siswa kelas VII di SMP Negeri 8 Kota Cirebon?

\section{Tujuan Penelitian}

Berorientasi dari rumusan masalah di atas, maka tujuan dari penelitian ini adalah sebagai berikut:

a. Untuk mengetahui penerapan pendekatan pembelajaran humanistik pada mata pelajaran IPS kelas VII di SMP Negeri 8 Kota Cirebon.

b. Untuk mengetahui hasil belajar siswa pada mata pelajaran IPS di kelas VII setelah menggunakan pendekatan pembelajaran humanistik di SMP Negeri Kota 8 Cirebon.

c. Untuk mengetahui pengaruh penerapanpendekatan pembelajaran humanistik terhadap hasil belajar siswa kelas VII di SMP Negeri 8 Kota Cirebon. 


\section{B. KAJIAN TEORI}

\section{Pengertian Pendekatan Pembelajaran Humanistik}

Teori humanistik lebih mengedepankan sisi humanis manusia dan tidak menuntut jangka waktu bagi pelajar untuk mencapai pemahaman yang diinginkan. Teori ini lebih menekankan pada isi/materi yang harus dipelajari dari proses membentuk manusia seutuhnya. Proses belajar dilakukan agar pelajar mendapatkan makna sesungguhnya dari belajar. Setiap orang memiliki kecepatan belajar yang berbeda-beda sehingga keberhasilan belajar akan tercapai jika seseorang mampu memahami diri dan lingkungannya. (Suprihatiningrum, 2013).

Dalam teori belajar humanistik, belajar dianggap berhasil jika peserta didik memahami lingkungannya dan dirinya sendiri. Siswa dalam proses belajarnya harus berusaha agar lambat laun mampu mencapai aktualisasi diri dengan sebaik-baiknya. Teori belajar ini berusaha memahami perilaku belajar dari sudut pandang pelakunya, bukan dari sudut pandang pengamatnya.

\section{Pengertian Hasil Belajar}

Hasil belajar sering disebut dengan istilah "sholastic achievement" atau "academic achievement" adalah seluruh kecakapan dan hasil yang dicapai melalui proses belajar mengajar di sekolah dan dinyatakan dengan angka-angka atau nilai-nilai berdasarkan tes belajar.

Untuk mengetahui tercapai tidaknya tujuan pembelajaran khusus, guru perlu mengadakan tes formatif pada setiap menyajikan suatu bahasan kepada siswa. Penilaian formatif ini untuk mengetahui sejauh mana siswa telah menguasai tujuan pembelajaran khusus yang ingin dicapai.

\section{Implementasi Pendekatan Pembelajaran Humanistik dalam Pelajaran}

\section{IPS}

Dalam prakteknya pendekatan humanistik ini cenderung mengarahkan siswa untuk berfikir induktif, mementingkan pengalaman, serta membutuhkan keterlibatan siswa secara aktif dalam proses pembelajaran.

Pembelajaran berdasarkan pendekatan humanistik ini cocok untuk diterapkan pada materi-materi pembelajaran yang bersifat pembentukan 
kepribadian, hati nurani, perubahan sikap, dan analisis terhadap fenomena sosial. Indikator dari keberhasilan aplikasi ini adalah siswa merasa senang bergairah, berinisiatif dalam belajar dan terjadi perubahan pola pikir, perilaku dan sikap atas kemauan sendiri. Siswa diharapkan menjadi manusia yang bebas, berani, tidak terikat oleh pendapat orang lain dan mengatur pribadinya sendiri secara bertanggungjawab tanpa mengurangi hak-hak orang lain atau melanggar aturan, norma, disiplin atau etika yang berlaku.

\section{Kajian Penelitian Relevan}

Hasil Penelitian Ardiansyah Qodir (2015) dengan judul "Pendekatan Humanistik dalam Pembelajaran Pendidikan Agama Islam di SMAN 1 Kota Probolinggo” dengan hasil sebagai berikut :

a. Hasil penelitian menunjukkan kenaikan kualitas aktivitas belajar siswa dan hasil belajarnya. Adapun kualitas belajar yang naik adalah keaktifan, kerjasama, ketelitian, dan tanggung jawab.

b. Sementara itu rata-rata nilai siswa sebelumnya 69,30 menjadi 84,17 pada akhir siklus. Dari data tersebut dapat disimpulkan bahwa penggunaan pendekatan humanistik dalam pembelajaran pendidikan agama islam di SMAN 1 Kota Probolinggo dapat menaikkan kualitas dan hasil belajar siswa.

\section{METODE PENELITIAN}

\section{Lokasi dan Waktu Penelitian}

Tempat yang dijadikan penelitian di SMP Negeri 8 Kota Cirebon. Waktu yang peneliti tempuh adalah selama 3 bulan, tepatnya pada bulan Januari sampai dengan bulan Maret 2018.

\section{Metode Penelitian}

Metode yang digunakan dalam penelitian ini adalah metode eksperimen yang bertujuan untuk melihat sebab akibat dengan memberikan suatu perlakuan. Dengan menggunakan metode eksperimen di perlukan beberapa kelompok pembanding atau kelompok kontrol (Arikunto 2002:79). 


\section{Desain Penelitian}

Desain penelitian ini dengan menggunakan pola menurut Arikunto (2002 : 79)
$\mathrm{A}: \mathrm{O}_{1} \quad \mathrm{X}_{1} \quad \mathrm{O}_{2}$
A : $\mathrm{O}_{1} \quad \mathrm{X}_{2} \quad \mathrm{O}_{2}$

Keterangan :
A : Pengelompokkan subyek secara acak
$\mathrm{O}_{1} \quad$ : Tes awal
$\mathrm{O}_{2} \quad$ : Tes akhir
$\mathrm{X}_{1} \quad$ : Perlakuan terhadap kelompok eksperimen, yaitu penggunaan pendekatan pembelajaran humanistik
$\mathrm{X}_{2} \quad$ : Perlakuan terhadap kelompok kontrol, yaitu pembelajaran dengan pendekatan pembelajaran biasa/konvensional.

\section{Populasi dan Sampel}

Populasi dalam penelitian ini adalah seluruh siswa kelas VII SMP Negeri 8 Cirebon yang berjumlah 273 siswa yang terdiri dari 9 kelas.

peneliti mengambil dua kelas dari sembilan kelas VII yang akan dijadikan sampel, sampel tersebut didapat dengan cara diacak/diundi dengan pertimbangan dua kelompok tersebut memiliki taraf kemampuan yang sama. Sampel diambil dua kelas yaitu kelas VII G sebagai kelas eksperimen dan kelas VII H sebagai kelas kontrol.

\section{Teknik dan Instrumen Pengumpulan Data}

a. Observasi

Nasution dalam Sugiyono (2016: 310) menyebutkan bahwa “obsevasi adalah dasar semua ilmu pengetahuan. Para ilmuan hanya dapat bekerja berdasarkan data, yaitu fakta mengenai dunia kenyataan yang diperoleh melalui observasi”.

b. Wawancara

Sugiyono (2014: 231) mendefinisikan "wawancara adalah pertemuan dua orang untuk bertukar informasi dan ide melalui tanya jawab, sehingga dapat dikonstruksikan makna dalam suatu topic tertentu”. 
c. Tes

Dalam penelitian ini tes yang digunakan adalah tes tertulis yaitupretes dan postes, tes ini dilakukan untuk mengukur seberapa besar penguasaan siswa pada mata pelajaran IPS ketika sebelum dan sesudah pembelajaran pada kelas eksperimen dan kelas kontrol.

d. Angket

Angket adalah alat yang digunakan untuk mengumpulkan data yang berupa daftar pertanyaan yang diberikan dengan kegiatan pembelajaran yang disampaikan kepada responden untuk dijawab secara tertulis pada kelas eksperimen untuk mengetahui bagaimana respon siswa terhadap pelajaran IPS dnegan menggunakan pendekatan pembelajaran Humanistik. (Yatim Riyanto 2001 : 87).

e. Teknik Dokumentasi

Dokumentasi merupakan catatan peristiwa yang sudah berlalu. Studi dokumen merupakan pelengkap dari penggunaan metode observasi dan wawancara dalam penelitian kualitatif. Dokumen bisa berbentuk tulisan (catatan harian, biografi, peraturan, kebijakan dan lainlain), gambar, atau karya-karya monumental dari seseorang (Sugiyono, 2014: 240).

\section{Teknik Analisis Data}

a. Uji Skala Prosentase

Pengumpulan data yang dilakukan uji prosentase ini yaitu dengan menyebarkan angket kepada siswa yang sudah menjadi sample penelitian.

b. Uji Normalitas

Uji normalitas digunakan untuk mengetahui apakah data penelitian berdistribusi normal atau tidak. Oleh karena itu sebelum pengujian hipotesis dilakukan maka terlebih dahulu akan dilakukan pengujian normalitas data.

c. Uji Homogenitas

Di samping pengujian terhadap normal tidaknya distribusi data pada sample, perlu kiranya peneliti melakukan pengujian terhadap 
kesamaan (homogenitas) beberapa bagian sampel, yakni seragam tidaknya variansi sampel-sampel yang diambil dari populasi yang sama. d. Analisis Butir Soal

Analisis butir soal dapat dilakukan dengan menghitung daya pembeda dan tingkat kesukaran.

e. Uji Analisis Korelasi

Uji variabel dalam penelitian ini yaitu menggunakan korelasi person product moment . uji korelasi bertujuan untuk mengetahui tingkat keeratan hubungan antara variabel yang dinyatakan dengan koefisien korelasi (r). Jenis hubungan antara variabel $\mathrm{X}$ dan $\mathrm{Y}$ dapat bersifat positif dan negatif. Apabila diperoleh angka negatif berarti korelasinya negatif. Ini menunjukkan adanya kebalikan urutan. Indeks korelasi tidak pernah lebih dari 1,00 (Arikunto, 2014).

\section{f. Koefisien Determinasi}

Koefisien determinasi adalah kuadrat dan koefisien korelasi dikalikan dengan 100. Koefisien determinasi dapat digunakan untuk melihat besarnya kontribusi variabel $\mathrm{X}$ dalam menjelaskan variabel $\mathrm{Y}$. Koefisiendeterminasi mengandung arti bahwa besarnya presentase varians variabel yang satu ditentukan oleh varians variabel lain (Subana, 2000).

\section{g. Analisi Regresi Linear}

Analisis regresi linear sederhana digunakan untuk menguji pengaruh satu variabel bebas terhadap variabel terikat. Syarat uji regresi linear sederhana adalah valid dan reliabel, juga normal dan linear. Regresi linear sederhana menjelaskan menganai hubungan antara dua variabel yang biaanya dapat dinyatakan dalam satu garis regresi, serta merupakan teknik dalam statistik parametrik yang digunakan secara umum untuk menganalisis rata-rata respon dari variabel $\mathrm{Y}$ yang berubah sehubungan dengan besarnya intervensi dari variabel X. 


\section{h. Uji “t”}

Uji Mann-Whitney (Wilcoxon) merupakan alternatif uji "t" yakni uji nonparametrik yang digunakan untuk membandingkan dua mean populasi yang berasal dari populasi yang sama.

\section{HASIL PENELITIAN DAN PEMBAHASAN}

Dalam pengumpulan data tentang "Pengaruh Pendekatan Pembelajaran Humanistik dalam mata Pelajaran IPSkelas VII di SMP Negeri 8 Cirebon”, pada penelitian ini menggunakan observasi, dokumentasi, Tes tertulis (Pre-test dan Post-test), angket dan wawancara secara langsung yang ditujukan kepada guru IPS kelas VII di SMP Negeri 8 Cirebon. Berdasarkan hasil observasi di kelas VII G dan kelas VII H yang dibimbing oleh Guru mata pelajaran IPS yaitu Ibu Ipah Masripah, S.Pd.

1. Respon Siswa Terhadap Pendekatan Pembelajaran Humanistik dalam Kegiatan Pembelajaran

Pada bagian ini akan dibahas mengenai respon siswa terhadap pendekatan pembelajaran humanistik pada materi tentang pasar di SMP Negeri 8 Cirebon. Untuk mengetahui respon siswa maka peneliti menjabarkan dengan angket, hasil angket dapat dijadikan patokan seberapa besar respon siswa terhadap pembelajaran IPS dengan menggunakan pendekatan humanistik dan mempunyai hubungan signifikan dengan penelitian.

Angket yang di sebarkan berjumlah 15 butir, lembar angket terdapat pada lampiran, 30 siswa menjawab angket yang diberikan peneliti, karena sebelumnya peneliti memberitahukan bahwa pengisian angket yang diberikan dapat menambah pengetahuannya. Siswa mengisi angket dengan baik, adapun hasil jawaban angket dianalisis menggunakan pogram SPSS.

Hasil analisis validitas instrumen variabel $\mathrm{X}$ di atas dapat dilihat pada $\mathrm{r}_{\text {hitung }}$ (Pearson Correlation). Nilai ini kemudian degan $r_{\text {tabel, }} r_{\text {tabel }}$ dari signifikansi 0,05. Kemudian jumlah responden 30, 
maka df $=\mathrm{N}-2$. Jadi 30-2 $=28$ di lihat dari $\mathrm{r}_{\text {tabel }}$ sebesar 0,361. Dari hasil analisis tersebut nilai $r_{\text {hitung }}>r_{\text {tabel }}$ sehingga angket tersebut dinyatakan telah valid.

Dari hasil data di atas, perhitungan reliabilitas instrumen angket variabel X (Pendekatan Pembelajaran Humanistik) ini diperoleh derajat instrumen sebesar 0,881 yang terletak pada kolom Cronbach's Alpha dari item 15 soal. Jika nilai $\mathrm{r}>\mathrm{r}_{\text {tabel }}$ maka instrumen dinyatakan reliabel. Adapun nilai $\mathrm{r}_{11}$ dari uji reliabilitas soal angket pada variabel X (Pendekatan Pembelajaran Humanistik) adalah 0,881 . Jika $r_{11}$ ini dikonsultasikan dengan nilai $r_{\text {tabel }}$ product moment dengan $\mathrm{df}=\mathrm{N}-1$ maka 30-1=29, signifikansi 0,05 maka diperoleh $r_{\text {tabel }}$ 0,355. Berdasarkan hal tersebut kesimpulannya adalah karena $r_{11}=0,881$, maka seluruh data variabel $\mathrm{X}$ dinyatakan reliabel dan tingkat keandalan reliabelnya menunjukkan pada tingkat yang sangat tinggi $\left(0,90<\mathrm{r}_{11}<1.00\right)$.

Berdasarkan hasil penelitian di SMP Negeri 8 Kota Cirebon, menunjukkan bahwa penerapaan pendekatan pembelajaran humanistik pada pokok bahasan pasar di SMP Negeri 8 Cirebon dapat dilihat dari hasil prosentase angket, yaitu sebesar 24,47\% (SS), 41,55\%(S), 19,34\%(KS), 10,44\%(TS), dan 4,20\%(STS). Hal ini menunjukkan bahwa pendekatan pembelajaran humanistik disukai siswa, selain itu juga ketika proses pembelajaran berlangsung siswa menjadi aktif dan antusias dalam belajar. Hasil analisi data angket pembelajaran humanistik mendapatkan respon yang "cukup” dari siswa dengan interval presentase (41\%-60\%). Hal ini ditunjukkan dengan sebagian besar siswa $(41,55 \%)$ menjawab setuju berarti dapat disimpulkan bahwa siswa merespon positif terhadap penerapan pendekatan humanistik dalam proses pembelajaran.

Seperti yang telah dijelaskan pada BAB II mengenai acuan teori, teori belajar humanistik berpendapat bahwa teori belajar apapun dapat dimanfaatkan asal tujuannya untuk memanusiakan manusia itu sendiri yaitu dengan mencapai aktualisasi diri, serta 
realisasi diri pada diri seseorang yang belajar secara optimal. Dalam pendekatan humanistik siswa diperlakukan sebagai subjek untuk membangun pengetahuannya sehingga siswa terlibat aktif didalam proses pembelajaran. Dan pada penelitian ini khusus mengkaji hasil belajar siswa pada materi pasar kelas 7 di SMP Negeri 8 Cirebon. Dimana kelas eksperimen yang diberi perlakuan dengan menggunakan pendekatan humanistik memperoleh nilai yang lebih baik dibandingkan dengan kelas kontrol yang menggunakan pendekatan konvensional.

Pendekatan humanistik yang mempunyai karakter Student Centered Approach digunakan penulis sebagai salah satu inovasi dalam pendekatan pembelajarannya, yang bertujuan untuk membimbing siswa agar berperan aktif dalam proses pembelajaran sehingga siswa dapat mengalami pembelajaran yang bermakna yang dengan belajar eksperiensial yang mengiringi siswa untuk berfikir induktif didalam memahami konsep-konsep yang ada dalam IPS.

Sebelum di bahas mengenai hasil belajar siswa peneliti terlebih dulu membahas pembuatan soal instrumen untuk uji coba, karena untuk mengetahui sebarapa besar peningkatan hasil belajar siswa dapat dilihat dari hasil pre-test dan psot-test, sebelum pre-test peneliti melakukan uji coba ter tertulis. Setelah uji coba soal tersebut valid dan layak untuk dijadikan instrumen penelitian. Peneliti melakukan tes pada kelas eksperimen sebanyak 30 siswa kemudian diterapkan pendekatan pembelajaran humanistik pada kelas eksperimen dan pembelajaran biasa pada kelas kontrol. Kemudian setelah materi selesai peneliti memberikan tes tertulis yaitu post-test guna mengetahui peningkatan hasil belajar siswa pada materi tentang pasar. Setelah itu peneliti mendapatkan data pre-test dan post-test yang akhirnya didapat nilai gain dari kelas eksperimen, untuk mengetahui peningkatan hasil belajar siswa pada pokok bahasan pasar maka peneliti mengambil nilai pre-test, post-test, dan gain pada kelas eksperimen. 
Rata-rata hasil belajar siswa dikelas eksperimen dan kelas kontrol dapat dilihat melalui tes (Pre-test dan Post-test) dengan soal pilihan ganda yang berjumlah 20 butir soal. Berdasakan hasil analisis, rata-rata hasil belajar siswa dikelas eksperimen secara keseluruhan dapat diketahui dari rata-rata nilai post-test sebesar 81,33 dengan kriteria gain 0,44, sedangkan rata-rata hasil belajar siswa dikelas kontrol sebesar 69,68 dengan kriteria gain 0,27. Dengan demikian dapat dilihat bahwa hasil belajar siswa setelah menggunakan pendekatan humnaistik meningkat dengan rata-rata 81,33 yang artinya hasil belajar siswa baik dengan interval persentase (76\%-85\%). Berdasarkan data tersebut dapat disimpulkan bahwa terdapat perbedaan rata- rata nilai pada hasil belajar siswa dikelas eksperimen dan kelas kontrol, sehingga adanya keberhasilan dalam penerapan pendekatan humanistik pada pembelajaran IPS.

Hasil belajar $=0,480+0,012$. Pendekatan pembelajaran

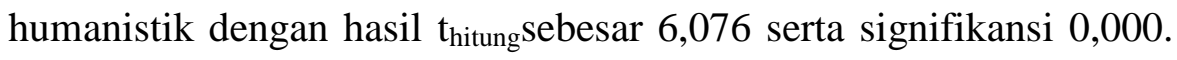

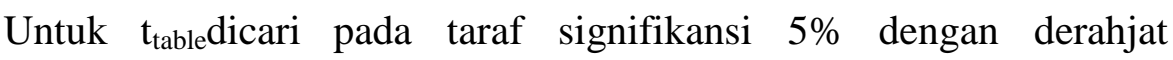
kebebasb (df) n-k-1 atau 30-2-1 = 27. Dengan pengujian dua sisi ( signifikansi $=0,05)$ hasil yang diperoleh untuk $t_{\text {tabel }}$ sebesar 2,05. Karena $t_{\text {hitung }}$ (6.076) lebih besar dari $t_{\text {tabel }}(2,05)$ maka $\mathrm{H}_{0}$ ditolak, yang artinya bahwa ada pengaruh penggunaan pendekatan pembelajaran humanistik terhadap hasil belajar siswa pada kelas eksperimen dalam hal ini kelas VII G SMP Negeri 8 Cirebon pada pokok bahasan pasar.

Dari hasil penelitian yang tertuang dalam skripsi ini yakni tentang pendekatan pembelajaran humanistik terbukti dapat mneingkatkan hasil belajar siswa. Dengan demikian diharapkan para guru dapat mengaplikasikan pendekatan pembelajaran humanistik dalam proses pembelajaran. Pendekatan humanistik mampu menciptakan kondisi belajar yang menyenangkan, sehingga para siswa dapat memahami materi pelajaran Dengan demikian, hasil belajar yang baikpun akan tercapai. 
Berdasarkan uraian dari hasil penelitian diatas, maka penelitian yang berjudul Pengaruh pendekatan pembelajaran humanistik terhadap hasil belajar siswa pada mata pelajaran IPS kelas 7 di SMP Negeri 8 Cirebon telah berhasil embuktikan hipotesisnya dengan baik. Sehingga penerapan pembelajaran IPS dengan pendekatan humanistik mampu meningkatkan hasil belajar siswa.

\section{E. KESIMPULAN DAN SARAN}

1. Kesimpulan

Berdasarkan hasil penelitian, penulis menyimpulkan sebagai berikut :

a. Penerapaan pendekatan pembelajaran humanistik pada pokok bahasan pasar di SMP Negeri 8 Cirebon dapat dilihat dari hasil prosentase yang menunjukkan bahwa hasil analisi data angket pembelajaran humanistik mendapatkan respon yang “cukup” dari siswa dengan interval presentase (41\%-60\%). Hal ini ditunjukkan dengan sebagian besar siswa (41,55\%) menjawab “setuju” berarti dapat disimpulkan bahwa siswa merespon positif terhadap penerapan pendekatan humanistik dalam proses pembelajaran.

b. Hasil belajar siswa yang pembelajarannya menerapkan pendekatan pembelajaran humanistik pada pokok bahasan pasar dikatakan baik. Adapun hasil belajarnya diperoleh skor rata-rata nilai Post-Test 81,33 dengan gain 0,44. Dengan demikian dapat dilihat bahwa hasil belajar siswa setelah menggunakan pendekatan humanistik meningkat dengan rata-rata 81,33 yang artinya hasil belajar siswa "baik” dengan interval persentase (76\%-85\%).

c. Penerapan pendekatan pembelajaran humanistik terhadap hasil belajar siswa berpengaruh signifikan dengan $t_{\text {hitung }}$ sebesar 6,076 serta signifikansi 0,000 . Untuk $t_{\text {table }}$ dicari pada taraf signifikansi 5\% dengan derajat keabsahan (df) n-k-1 atau 30-2-1 $=27$. Dengan pengujian dua sisi (signifikansi $=0,05$ ) hasil yang diperoleh untuk $t_{\text {tabel }}$ sebesar 2,05. Karena $t_{\text {hitung }}$ (6.076) lebih besar dari $t_{\text {tabel }}(2,05)$ maka $\mathrm{H}_{0}$ ditolak, yang artinya bahwa ada pengaruh penggunaan pendekatan pembelajaran humanistik 
terhadap hasil belajar siswa pada kelas eksperimen dalam hal ini kelas VII G SMP Negeri 8 Cirebon pada pokok bahasan pasar.

2. Saran

Dalam hasil penelitian yang tertuang dalam skripsi ini yakni tentang pengaruh pendekatan pembelajaran humanistik terbukti dapat meningkatkan hasil belajar siswa, dengan demikian diharapkan untuk para guru agar dapat mengaplikasikan pendekatan pembelajaran tersebut dalam proses pembelajaran.

Semoga skripi ini dapat berguna bagi semua pihak baik yang membaca maupun yang mempelajarinya, tertama bagi guru IPS dan calon guru IPS. Semoga dengan diketahuinya keefektifan pembelajaran dengan menggunakan pendekatan pembelajaran humanistik ini dapat diaplikasikan dalam proses pembelajaran sehingga akan tercapainya hasil belajar yang diharapkan.

\section{DAFTAR PUSTAKA}

Ahmadi, Abu dan Prasetya, Joko. 2005. Stategi Belajar Mengajar. Bandung : Pustaka Setia.

Arikunto, Suharsimi. 2002. Prosedur Penelitian. Jakarta : Rineka Cipta.

Baharuddin dan Wahyuni Nur Esa. 2015. Teori Belajar dan Pembelajaran. Yogyakarta : AR-Ruzz Media.

Jarvis, Matt. 2000. Teori-Teori Psikologi (Pendekatan Modern untuk Memahami Perilaku, Perasaan dan Pikiran Manusia). Bandung : Nusa Media.

Nadir, dkk. 2009. Pendidikan Ilmu Penegtahuan Sosial. Jakarta : Rineka Cipta.

Riyanto, Yatim. 2001. Metodologi Penelitian Pendidikan. Surabaya : SIC.

Subana, dkk. 2000. Statistik Pendidikan. Bandung : Pustaka Setia.

Sugiyono. 2017. Metode Penelitian Pendidikan: Pendekatan Kuantitatif, Kualitatif, dan R\&D. Bandung: Alfabeta. 
